\title{
Universities as Intermediaries: Impact Investing and Social Entrepreneurship
}

\author{
Rebecca Tekula,Archana Shah, and Jordan Jhamb
}

\begin{abstract}
Metropolitan universities are well poised in communities to be intermediaries among various actors involved in social innovation. Pace University established one of the first institutes on social entrepreneurship. Its unique position at the university level allows programming to transcend certain institutional challenges. The emerging field of impact investing is fertile ground for partnerships allowing the university to serve as resource provider, while benefiting from myriad opportunities for student and faculty engagement, experiential learning, and access.
\end{abstract}

The emergence of social entrepreneurship has planted the seeds for an increasing number and variety of educational activities related to the field. As the world of social ventures evolves, from traditional charity to social enterprise and social entrepreneurship, the academic pathways provided must advance accordingly. Careers in the social sector are growing, along with a clear demand for courses, programs, and learning experiences that equip students with the knowledge and hands-on experience needed to succeed in the field. A key learning outcome of social entrepreneurship education is the development of skills and acquisition of knowledge to mobilize resources from various institutional spheres (Seelos et al. 2011). Metropolitan universities are often well poised in their communities to act as intermediaries or hubs among the various domains and institutional actors involved in social innovation and to support the communities in which they reside.

The true arrival of social entrepreneurship education took place only in the very early twenty-first century when a small but growing number of universities had started to support the social enterprise movement and the use of business practices in the nonprofit sector. While the emergence of social entrepreneurship planted the seeds for an increasing number and variety of educational activities related to the field, the question remained: How could a metropolitan university, with limited resources, build upon its strengths and partners to contribute meaningfully to social innovation?

Pace University, as an early actor in the domain, decided to make a strong commitment to the emerging field of social entrepreneurship by establishing the Helene and Grant Wilson Center for Social Entrepreneurship and positioning it uniquely at the university level, and not within a school or college. With an aim to support and connect with faculty, students, and alumni from across the university, the center was created with an eye to the truly interdisciplinary aspects of social innovation. The relevance of this positional strategy is underscored by Pache and Chowdhury (2012) who emphasize that while social entrepreneurs engage in activities 
similar to all entrepreneurs, the context of their work is different and, therefore, requires an education that brings to bear distinctions and differences of three logics: social-welfare, commercial, and public-sector. However, in spite of this, the overwhelming majority of social-entrepreneurship/enterprise-education programs are based in business schools, with a core education program.

\section{Background}

Pace University evolved from thirteen students studying accounting in a rented classroom in 1906 to today's diverse university featuring more than 13,000 students in bachelor's, master's, and doctoral programs in six schools: College of Health Professions, Dyson College of Arts and Sciences, Lubin School of Business, School of Education, School of Law, and Seidenberg School of Computer Science and Information Systems.

Located on multiple campuses in New York City and Westchester County, Pace is a truly metropolitan university. The main New York City campus is located in the civic center of Lower Manhattan, an intellectual and cultural focal point for one of New York City's most dynamic and revitalized areas. This location benefits from exciting opportunities and interactions between the university community and the Lower Manhattan community at large. Pace New York City also includes a Midtown Center, located on Fifth Avenue just blocks away from Grand Central Station and Times Square. This location hosts the Masters in Publishing degree program due to its proximity to major publishing houses. It also offers a selection of weekday and evening classes and certificate programs; the location is convenient for many working professionals.

In mid-Westchester, Pace's Pleasantville campus and Briarcliff location are set on 200 acres of rolling countryside where the university is identified as a preeminent institution of higher education. The Pleasantville campus offers a broad range of undergraduate degree programs and graduate programs in nursing. In 1977, Pace acquired Briarcliff College, ten miles from Pleasantville in Briarcliff Manor. Residence halls, recreational facilities, and administrative offices are located here. Pace administers these locations together and provides shuttle bus service between the campuses.

Lastly, Pace's White Plains Campus, located diagonally across the street from the White Plains Railroad Station, is home to programs in business, public administration, and computer science. Since 1976, it has also housed the Pace University School of Law, the only law school between New York City and Albany.

Academic experiences at Pace emphasize teaching from both a practical and theoretical perspective, drawing on the expertise of full-time and adjunct faculty members who balance academic preparation with professional experience and capitalize on the advantages of the New York Metropolitan Area to bring a unique dynamic to the classroom. Additionally, civic engagement is deeply rooted in the fabric of Pace's culture. In 1956, the Pace College Board of Trustees and faculty expressed their philosophy of education when they wrote, "The educational offerings 
of the institution should be directed toward developing citizens who are able and willing to take leadership in business and related professions, and who are equipped to contribute to the larger community and of the nation." Today, at Pace, every school contributes community service courses to the core curriculum. During the 2012-2013 academic year, more than 2,200 students enrolled in 117 sections and spent more than 55,000 hours in community service. Pace students address issues in community service that often define their careers and our futures.

In a broader context, the need for thoughtful well-educated leaders in a variety of nonprofit sectors is growing. Nonprofits employ around 10 percent of the American workforce, and over 18 percent of the workforce in New York State (Salamon, Sokolowsi, and Geller 2012). There are more than 1.6 million registered nonprofits in the United States. In 2010 public charities reported \$1.51 trillion in revenue and \$2.71 trillion in total assets (Roeger, Blackwood, and Pettijohn 2012). Pace University represents a microcosmic example of the nonprofit sector's impact. In the last five years, 20 percent of all reported job and internship placements of Pace students have been in nonprofits and government. Furthermore, this data indicates that 40 percent of Pace University's Dyson College of Arts and Sciences graduates find full-time employment in nonprofits and government, and 33 percent in nonprofits alone.

\section{What Is the Wilson Center?}

In 2005, the Helene and Grant Wilson Center for Social Entrepreneurship was created to serve the nonprofit community and Pace University. Devoted to honing the risktaking spirit and managerial skills of nonprofit organizations, the center was launched with a pledge from Helene and Grant Wilson, Boston-area entrepreneurs and philanthropists whose charitable endeavors convinced them that entrepreneurial management can help social ventures increase their impact. The mission of the center is "to promote social change through entrepreneurship." Working across all disciplines, the center has endeavored to further this mission by serving the Pace University community, social enterprises, and nonprofit organizations with education, research, communication, and advisory service.

\section{What Is Social Entrepreneurship?}

Social entrepreneurship is the process of pursuing innovative solutions to social problems (Dees 2001). These novel solutions are "better than existing approaches (i.e., more effective, efficient, sustainable, or just) and the value created (benefits) accrues primarily to society as a whole, rather than private individuals" (Phills, Deiglmeier, and Miller 2008, 36). For example, social concerns such as financial access for disenfranchised populations at the base of the pyramid have been addressed with innovations like microfinance.

For social enterprises to form, these innovative solutions need to be scalable and sustainable. They need to create social impact in a financially sustainable way, by applying commercial strategies. Furthermore, real social impact comes with scale-the 
ability to affect large populations with the social innovation is also critical and plays into the viability of the social enterprise. Social enterprises are typically hybrid organizations that can be structured as for-profit or nonprofits, with the mixed motives of balancing social and economic value creation (Dees 2001).

\section{Funding Social Innovation}

Traditionally, social problems have been addressed by government funding or by charitable giving through foundation grants, individual giving, and corporate giving. While this pool of capital is substantial, it dwarfs the potential capital that could be harnessed toward investing in innovative solutions to persistent problems in our society. As of 2010, private contributions and government grants together made up less than 25 percent of revenue sources for reporting public charities (Blackwood, Roeger, and Pettijohn 2012). If we examine the foundation data further, in the United States collectively, foundations have approximately $\$ 600$ billion in assets (Roeger, Blackwood, and Pettijohn 2012), however, only fifty billion dollars are spent on social problems in the form of grants to nonprofits. This amount meets the 5 percent qualified distribution (Chen 2012) required by law, however, the other $\$ 550$ billion in investment capital is largely dormant with respect to mission. We are seeing small changes; innovative foundations have started making program-related investments (PRIs) and mission-related investments (MRIs) to deploy more capital toward social impact. These instruments, while not formally defined, have the characteristics of a loan. PRIs are zero percent to below-market interest rate loans that must primarily serve a charitable purpose (i.e., social impact) (Levitt 2011). PRIs are counted within the 5 percent qualified distribution minimum, and as such do not affect the $\$ 550$ billion in assets held by foundations. However, PRIs differ from grants in that they are investments, and the principle is expected to be paid back. MRIs are also loan-type investments for social impact; however, they differ from PRIs in that they demand a market-rate financial return. Like PRIs, the principle of an MRI is expected to be paid back at the end of the investment period. The catalytic aspect of MRIs is that they do not count toward the 5 percent qualified distribution minimum, and as such are sourced from the $\$ 550$ billion foundation assets, thus unlocking more foundation capital for social impact.

While MRIs and PRIs remain marginal strategies amongst private foundations in the United States, there are some exceptions. One of these cases is the recent strategic shift of the F. B. Heron Foundation. In their 2011 Foundation Strategy, F. B. Heron declared a move to deploy all their assets toward mission. Over the past three years, F. B. Heron has evolved from a solely grant-making approach, to making a combination of grants, PRIs, and MRIs, depending on the need and capacity of the intended organization or investment. Through this progression, their goal is to have 100 percent of their assets deployed for mission. To quote the organization: "We no longer believe that the legal requirement of using just 5 percent of endowment assets to make grants, 
while leaving the rest traditionally invested, is adequate to achieve the scale of social change we would like to see" (The F. B. Heron Foundation 2014, 1). An increasing number of foundations in the United States are making their first MRIs, which will in effect test this process in each individual operating structure.

Changing the ecosystem of a foundation is challenging; it requires a complete overhaul in the skill set of the personnel from traditional grant makers to investment analysts. With more assets invested and at risk, it also requires a robust risk-management system; both pre-investment rigorous due diligence and on-going risk management becomes crucial.

\section{From \$550 Billion to \$210 Trillion}

Evolving foundation strategies have the potential to unlock over $\$ 550$ billion in assets; however, private markets hold an estimated $\$ 210$ trillion in assets (eighty trillion dollars in pension and institutional funds alone) (Rockefeller Foundation 2014). Needless to say, unlocking private capital for social change has the potential to be transformative. The lack of funding opportunities is one of the major disadvantages social enterprises face. A conventional business can use its balance sheet and business plan to offer different combinations of risk and return to many different types of investors: equity investors, banks, bond funds, venture capitalists, and so on. Not so for many social enterprises, but that is changing. An increasing number of social entrepreneurs and investors are realizing that social enterprises of all sorts also can generate financial returns attractive to investors. This realization can lead to a dramatic increase in the amount and diversity of capital available to these organizations. Essentially, the insight is that one can treat the funding of a social enterprise as a problem of financial structuring. One such social finance innovation is Social Impact Bonds (Goldman Sachs 2014).

\section{The Evolution of Impact Investing}

Social enterprises are increasingly tapping into this growing market of hybrid capital. In its early stages, a social enterprise can tap into more traditional philanthropic capital for grants and low-cost funding. These investors do not expect a financial return, but expect a social return. As the enterprise matures and is generating revenue, this will attract market-rate investors who expect both a financial and a social return. These hybrid investors, often referred to as impact investors, are typically crossover philanthropists, but increasingly include traditional investors seeking both measurable social and financial returns on their investments. According to the Global Impact Investing Network (GIIN), "Impact investments are investments made into companies, organizations, and funds with the intention to generate a measurable, beneficial social or environmental impact alongside a financial return" (Global Impact Investment Network 2014a, 1). 


\section{Measuring Social Impact}

Today, in order to attract meaningful investment capital, social innovations must have measurable and reportable outputs and outcomes. Anecdotes are no longer a sufficient means of demonstrating program effectiveness. As GIIN explains, "Impact measurement is central to effective impact investing, as it demonstrates investor intent and legitimizes the industry with data on impact produced. Good impact measurement generates intrinsic value for all impact investment stakeholders, yields data to mobilize greater capital toward generating impact, and increases the transparency and accountability for the impact delivered" (Global Impact Investment Network 2014b, 1). GIIN has done some groundbreaking work on impact metrics, in particular the establishment of the Global Impact Investing Ratings System (GIIRS), a system for assessing the social and environmental impact of companies and funds with its ratings and analytics approach (Global Impact Investing Ratings System 2014). GIIRS is intended to be analogous to Morningstar investment rankings and Capital IQ financial analytics, and become the standard metric measurement tool. As it is adopted by more investors and social enterprises, it may catalyze the impact investment movement; this tool is intended to change investor behavior and unlock the potential of this new asset class.

The Wilson Center is based on Pace University's Lower Manhattan campus. Lower Manhattan is the fourth largest business district in the United States, one of the fastest growing residential neighborhoods in the city, a popular tourist destination, and one of the main transportation hubs of New York City. As a neighbor to city hall and several city, state, and federal agencies, Pace University has served as a community partner on a variety of important initiatives.

To fulfill its mission, the Wilson Center adopted a four-pronged strategy, outlined below:

\section{Inspired Education}

This program area focuses on cultivating the next generation of nonprofit and social enterprise leaders. This includes leading and facilitating the development of curriculum for both noncredit and degree-granting programs at the undergraduate and graduate level.

1. Leading up to fall 2013, the Wilson Center, in partnership with the Dyson College of Arts and Sciences, was integral in the development and establishment of a minor in nonprofit studies. By spring 2014, more than 200 undergraduate students were enrolled in minor-eligible undergraduate courses, reflecting their interest in the sector. As of fall 2014, students enrolled in the nonprofit studies minor have majors in advertising and integrated marketing, political science, psychology, theatre arts, English literature, and history, to name a few, truly reflecting the cross-disciplinary interest in the field. This academic credential allows Pace students to connect their passion for social impact into their career path and future planning.

2. Wilson Center advisors, fellows, and other faculty partners across several schools instruct a number of courses at the undergraduate and graduate level, including: 
i. CS 643 Mobile Innovations for Global Challenges

ii. FIN 680/360 Microfinance and Small Business Financing in India

iii. MGT 349 Global Sustainable Development

iv. MGT 678 Advanced Topics in Management: Social Entrepreneurship

v. PAA 683 Seminar in Social Entrepreneurship

vi. PSJ 301 Humanitarianism and International Aid Work

vii. WS 305 Philanthropy on a Mission: Women and Change in the Nonprofit Sector

3. The Wilson Center supported the extension of the Master in Public Administration program from the White Plains Campus, where it resided for thirty years, to the Lower Manhattan campus in order to meet the growing demand from the local nonprofit community. This program attracted twenty-three new students in its first semester.

4. The Wilson Center has a long standing partnership with United Way of Westchester and Putnam Counties. Through this collaboration, Pace's Westchester County campus provided eighteen continuing education workshops to over 224 nonprofit managers in the county this past year. These workshops also serve as a pipeline into Pace's MBA and MPA degree programs.

\section{Research to Practice}

The goal of this program area is to support the creation of a diverse portfolio of recognized research projects related to social innovation, social finance, social entrepreneurship, and nonprofit management. Faculty fellows are funded and supported in: 1) initiating and developing research studies, 2) promoting their work at talks and conferences, 3) submitting their research to leading publications and peerreviewed journals, and 4) applying for sponsored research grants from government agencies and private foundations.

1. Sponsored Research. Each year, the Wilson Center funds four faculty fellows. A faculty steering committee sets funding priorities and selects candidates through a blind review process. Selected fellows work on specific projects - generally case studies and academic research - related to the center's mission. Each recipient is awarded $\$ 5,000$ and is supported by student research assistants. Since 2009, this program has produced twenty-five research papers.

2. Brown Bag Lunch Research Seminars. The Wilson Center hosts a series of brown bag lunch seminars which showcase past faculty fellow-funded research projects. For accessibility, the seminars are held during common hour and are webcast to the Pace online community. 
3. Nonprofit and Social Enterprise Research. The Wilson Center is a research and data resource for both local and national organizations, including the Westchester County Executive and local congressional representatives. The center also offers research support in service of the university; the Economic Impact Report for Pace NYC and the Economic Impact Report for Pace Athletics were based on research by the center. Center-based faculty and staff also actively write and publish relevant research.

4. Digital Commons Initiative. The Wilson Center's Digital Commons Selected Works series serves to maximize the visibility and impact of its research. This repository is home to many online journals including the Pace Environmental Law Review, the Yale Journal of Health Policy, Law and Ethics, and Cornell University ILR Review. Works posted in the center's series have had 2,475 full-text downloads since 2013.

The leverage of these seed research grants is illustrated in the example of one past faculty fellow, Professor Christelle Scharff of Pace's Seidenberg School of Computer Science and Information Systems. She worked on innovative research exploring mobile technology for social change in Africa. In addition to the faculty fellowship, the Wilson Center sponsored her attendance at a conference to present her work, which was also showcased at a Student Leadership Forum on campus. Her paper was published in the Journal of the Frontiers in Education Conference. From this, Professor Scharff created a course and launched a mobile app contest for students. Consequently, Dr. Scharff received a Fulbright Fellowship for her work, and she is now Chair of the Computer Science Department.

\section{Recognized Voice}

The center aims to be a recognized center of excellence in the field of social enterprise, both internally at Pace University and externally in the community.

1. External Visibility. The Wilson Center is recognized by Ashoka, Echoing Green, and the U.S. Department of State as a thought leader in best practices in social enterprise and entrepreneurship. The center hosts a series of conferences and speaking events throughout the year as a platform to foster critical conversations with key stakeholders. These events are free and open to both the Pace and New York nonprofit and government communities. These events include:

i. Pace-Hitachi Nonprofit Forum: This annual free educational forum held on the White Plains campus, hosts more than 150 attendees each year and is cosponsored by Hitachi America, Ltd. A significant number of students attend this event, and a career networking luncheon is served for students, alumni, and employers.

ii. Not-for-Profit Leadership Summit: The Wilson Center is a co-sponsor of this full-day annual gathering of more than 700 nonprofit leaders in Westchester. All Pace University students are invited to attend for free. 
iii. U.S. Department of State Social Entrepreneurship Panels and Courses: The Wilson Center has an ongoing partnership with the U.S Department of State and leads a panel or course on social entrepreneurship for international delegates through the State Department Visitors Program; up to ninety delegates attend each year.

iv. True Partnerships Discussion: The Wilson Center sponsors an annual event on the Lower Manhattan campus bringing together social ventures and their partner organizations and sponsors to discuss best practices for collaboration toward social impact.

v. NYC Nonprofit Career Panel: Each year, the Wilson Center hosts a panel on social sector career opportunities. Recent Pace alumni working in the nonprofit, government, and social enterprise sectors return to campus and speak with students about their experiences in the sector thus far. Students benefit from engaging with practitioners in the field and have a chance to network and connect with the alumni speakers.

2. Internal Visibility: To be a further resource to the Pace community of faculty, staff, and students, the Wilson Center produces and publishes short ten-to-twelve minute teaching/learning modules on topics related to social entrepreneurship. These are made accessible to the Pace community through the Blackboard Learning System and encourage faculty to import relevant modules into their course syllabi. Wilson Center faculty and staff researchers also guest lecture on relevant topics in-person in the classroom by invitation.

3. Communications. The Wilson Center's website provides an important connection to members of the Pace University community and the social sector. The center's website, weekly online newspaper, and related social media tools are used to engage students and alumni in activities at Pace and in the community related to the center's mission.

4. Public Relations. The Wilson Center is featured in the local and national press, with coverage of both research and program activity. For example, at the request of a local reporter, the Wilson Center recently led an analysis on the trends and issues faced by the large and growing nonprofit sector in Westchester. The report served as two separate features in a local magazine and led to an invited presentation for Congresswoman Nita Lowey.

\section{Energetic Community}

The Wilson Center goal of fostering a collaborative community of faculty, students, alumni, and practitioners is realized through a suite of experiential learning opportunities for students to enhance their education. The center offers several experiential programs: 
1. Summer Funded Internships: Since 2009, the center has placed and funded seventynine full-time summer internships at forty-seven unique and innovative nonprofits and social enterprises in the New York metro area. Interns in the program represent a wide variety of majors across Pace's six schools, with undergraduate and graduate students participating at nearly equal rates. Each intern receives $\$ 4,200$ in income for the summer, resulting in $\$ 373,800$ in funding over the last six years. This year, the Wilson Center was able to expand the scope of the program into Staten Island and Queens with restricted institutional funding. For the summer 2014 program, the Wilson Center received 216 applications for thirteen positions at hosts including the F. B. Heron Foundation, The National Museum of the American Indian, and the Staten Island Economic Development Corporation. In addition to a salary, these students benefit from professional development and mentorship opportunities provided by their host organizations.

2. Student Run Fund Appropriations Committee: Eight student leaders allocate up to $\$ 84,000$ in funding each year-approximately twenty internships - by reviewing and selecting intern hosts and positions.

3. Student Research Assistants: The Wilson Center hosts two to three student research assistants each year who work on a variety of in-house research projects in collaboration with the staff. Wilson Center interns have a 100 percent graduation and job placement rate.

4. Student Sponsorship is offered for a variety of related and/or co-sponsored events and conferences off campus.

5. Social Ventures: The Wilson Center, in collaboration with the Entrepreneurship Lab at Pace University, has helped launch more than ten unique student social ventures; winners have been awarded more than $\$ 26,000$ in prizes.

6. A Conversation on .... This speaker series has included leaders from SAP Corporate Social Responsibility, Network for Teaching Entrepreneurship, First Access, the F. B. Heron Foundation, and Grameen America to name a few, on topics ranging from impact investing, technology, and social impact to conversations on best practices in nonprofit-corporate partnerships. These events are sometimes scheduled in partnership with faculty teaching a course on a specific, related topic, or as stand-alone events to foster interesting relevant conversation on the sector, sponsored by the Wilson Center.

7. Social Enterprise in Residence: Each year, the Wilson Center hosts a Social Enterprise in Residence. The current in-residence organization is Impact America Fund, an early-stage GIIRS-rated equity firm that invests $\$ 250,000$ to $\$ 2,000,000$ each in high growth companies generating real financial returns while improving the well-being of underserved communities. Their investments are focused on 1) health and well-being, 2) education, 3) essential services, and 4) financial security. 
The Helene and Grant Wilson Center for Social Entrepreneurship at Pace University plays a critical role in raising awareness amongst the student population about this changing sector. As a truly interdisciplinary institute, the center can engage students from across the university in these innovative opportunities.

\section{Spotlight on the Social Enterprise in Residence Concept at Pace University}

To understand the concept and operation of a Social Enterprise in Residence program at Pace University, it is important to highlight the aforementioned civic engagement focus of the institution.

Strong collaborative partnerships are critical to the success of any university in its efforts to build social innovation programming and pedagogy. At Pace University, each year the Helene and Grant Wilson Center for Social Entrepreneurship brings a respected Social Enterprise in Residence into the Pace University community. The leadership of these organizations share experience and wisdom and help the Pace community to understand the challenges and opportunities facing social ventures. Leaders of social enterprises have shared how they started their organization, what they have accomplished, and how they plan to further their mission.

The Wilson family provided generous funds for the creation of the Wilson Center, and in the earlier years of operation, the center annually hosted Social Entrepreneurs in Residence. These individual leaders would visit campus to share experiences and wisdom, helping the Pace community to understand the challenges and opportunities facing nonprofit organizations and social change leaders in the community. The center launched the in-residence program in fall 2005, naming Susan Rodgerson as its first social entrepreneur in residence. Rodgerson was the first of several social entrepreneurs that visited campus to share how they started their organization, what they had accomplished, and how they planned to further their mission. Subsequent social entrepreneurs in residence include Charles Best, founder of DonorsChoose.org, and the MacArthur "Genius" award winner Majora Carter, founder of Sustainable South Bronx.

Busy as they were, these social entrepreneurs were able to visit campus for one or two days, and engage in, at most, two speaking engagements and some classroom time during their visit. While these engagements were met with enthusiasm, there was more demand than could be met for opportunities to learn from and interact with these individual leaders. Thus, in early 2009 , the advisory committee discussed and agreed to shift from an individual entrepreneur-in-residence model, to an enterprise-inresidence model. The aim of this new direction was to continue to attract nonprofit and social enterprise leaders from the New York City metropolitan area, while growing the in-residence opportunity to a more holistic and multifaceted perspective of social innovation. By partnering with entire organizations, we could provide relevant and accessible models for students and faculty while supporting and partnering with the 
organization overall. While not restricted to an individual organizational leader's schedule, it would be possible to identify more presentation and meeting times, collaborative programs, research projects, and other partnership opportunities convenient for the social enterprise leadership team, students, faculty, and staff.

The Social Enterprise in Residence program essentially was structured to have three key elements that include organizational representatives 1) giving at least one public talk and leading one seminar session in their specialty, 2) making a small number of guest presentations to Pace University classes, and 3) hosting at least one Pace University student as a Wilson Center funded summer intern.

The process of selecting a social enterprise in residence was designed to be formal, requiring a nomination from an advisory committee member, a demonstrated existing partnership with the university or center, and a formal submission by the center directorship to the provost for approval. For stable partnership, the designation is designed to be renewed for one year, provided there was a successful track record in the initial year.

\section{Current Social Enterprise in Residence}

Based on an existing collaborative partnership, the Wilson Center selected Impact America as its Social Enterprise in Residence for the 2014-2015 academic year. Impact America is an early-stage GIIRS-rated equity firm that invests $\$ 250 \mathrm{~K}-\$ 2 \mathrm{M}$ in high growth companies generating real financial returns while improving the wellbeing of underserved communities and creating quality jobs in America. Impact America invests in diverse entrepreneurs who are directly improving the quality of life in underserved communities, scaling businesses focused on four major areas: 1) health and well-being, 2) education, 3) essential services, and 4) financial security.

Kesha Cash, founder and director of investments at Impact America, had been actively engaged with Pace University for several years prior to the nomination for Social Enterprise in Residence. She served as a guest lecturer in a graduate microfinance class and in the Encore career transitions program, and had met with and mentored several Pace University students one-on-one. These early meetings and collaborations led to a joint research project, The State of Black Entrepreneurship in the United States, and a funded speaking engagement on these findings by Rebecca Tekula, director of the Wilson Center, at the launch of the Historically Black Colleges and Universities Venture Catalyst Program at the United Negro College Fund's annual capacity building conference.

\section{University Role in Impact Investing}

University centers typically focus on a particular industry or field, and generally have a goal related to thought leadership and knowledge creation in that area. Ideally, such centers also reflect a partnership of academia, government, and industry. Impact investing as an emerging field is a ripe ground for the academe to play an active role, 
offering resources and support during nascent development stages, whilst consequently developing opportunities for engagement, experiential learning, and access for students, faculty, and community. By positioning the university as incubator, whether formal or informal, centers can become a direct provider and intermediary of resources in an emerging field. Furthermore, as the field develops, there is an immediate need for data, research, and analysis, which faculty and researchers are able to provide. Conversely, impact investing is great fodder for case study development. Students, at both the undergraduate and graduate levels, are also a key resource to new ventures as interns and part-time staff.

In the case of the Wilson Center's partnership with Impact America, a multitude of high-impact educational practices have emerged. From the earliest days of the partnership, an opportunity was presented to develop an undergraduate student coauthored research report related to the demand for minority entrepreneur access to capital. This led to a funded presentation at the aforementioned conference. In this more formalized in-residence relationship with the fund, which itself is only in its first academic semester, the center has placed students in funded internships with Impact America and the F. B. Heron Foundation, an important institutional funder making waves in the field.

The Wilson Center's growing presence in the field of impact investing in New York City has led to a number of new partnerships. The center recently engaged with the Global Impact Investing Network (GIIN), a neighbor in Lower Manhattan. GIIN's s Impact Reporting and Investment Standards (IRIS) manager was one of three judges at Pace's annual pitch contest, bringing a social impact lens to the ventures being pitched. Most recently the center hosted the Director of Clients and Partnerships at First Access, a New York-based social enterprise, to speak with graduate nonprofit management students and graduate computer science students.

\section{Impact Investing on Campus}

Impact investing has in effect become a theme of the Wilson Center programming in recent months. A social finance topic was selected for the center's annual nonprofit forum, co-sponsored by Hitachi America, Ltd., on the Westchester County campus. A panel event on impact investing was hosted on the New York City campus. Identifying speakers for these events has proven relatively easy. The marketplace for academic partnerships has not fully developed for impact investing, thus, as early actors, the university has had great success tapping into the network of practitioners in the field. Faculty and staff have used this access as a jumping off point to develop publications on impact investing and social finance. In response to the overwhelming demand to share this developing expertise with students and faculty, the center has begun to develop and test a series of teaching modules to share with faculty for import into their Blackboard course shells. These modules are created in the form of Echo360 recorded lectures paired with discussion-starter questions, discussion board postings, and even short writing assignment suggestions. 
Impact investing and social finance in general, has proven an effective, contemporary, and refreshing vehicle through which to view and carry forward the university's community service and civic engagement roots. Acting as a catalyst and supportive partner in this emerging field has allowed learning opportunities, and real-time access and cases for research and teaching. The innovation inherent to this field has proven a natural fit for engaging across disciplines; partners and opportunities abound which are compelling, accessible, and relevant for students from departments and majors as diverse as women's studies, computer science, and finance.

\section{Conclusion}

The social sector is changing and growing rapidly, and as such universities are challenged to innovate and keep current both curriculum and co-curricular activities, as they serve students on their path in the field. Pace University was an early actor in this sphere, establishing one of the world's first funded, staffed institutes dedicated to social entrepreneurship. The Helene and Grant Wilson Center for Social Entrepreneurship, and its growth and impact, has benefited from a unique position at the university level, which allows programming to transcend certain institutional challenges. The center's geographic location in Lower Manhattan, which is the seat for many government agencies and social sector organizations, has further proven to be a great strength for building programs and partnerships in the field.

While neither social innovation institutes nor in-residence programs are unique to Pace University, the Wilson Center's truly interdisciplinary approach and distinctive partnership with the Impact America fund may well represent a new method and partnership pipeline. Ideally, university centers reflect a partnership of academia, government, and industry. The emerging field of impact investing and social finance has proven to be fertile ground for partnerships that allow the university to serve as resource provider and supporter, while conversely offering myriad opportunities for student and faculty engagement, experiential learning, and access. Positioning the university as incubator and supporter in emerging fields, and particularly areas of the social sector, which by nature are challenged to meet market failures, can prove duly rewarding: students and faculty are engaged in meaningful, relevant ways, and the university and curriculum are kept current on trends, challenges, and opportunities in the field.

\section{References}

Alter, Kim. 2004. "Social Enterprise Typology.” Virtue Ventures LLC. Accessed November 12. http://www.virtueventures.com/resources/setypology.

Alter, Kim, and Vincent Dawans. 2009. "The Four Lenses Strategic Framework." Virtue Ventures LLC. Accessed October 15. http://www.virtueventures.com/files/fourlenses.pdf. 
Barr, S., Kevin Johnson, Wendy Kopp, and Michelle Rhee. 2008. "The Role of Social Entrepreneurship in Transforming U.S.A. Public Education.” The Centennial Global Business Summit. Harvard Business School. Accessed August 22. http://www.hbs.edu/centennial/businesssummit/business-society/the-role-of-socialentrepreneurship-in-transforming-usa-public-education-2.html.

Blackwood, Amy, Katie L. Roeger, and Sarah L. Pettijohn. 2012. The Nonprofit Sector in Brief: Public Charities, Giving, and Volunteering. Washington, D. C. Urban Institute.

Brock, D. D., and Ashoka University. 2011. "Social Entrepreneurship Education Resources Handbook." Ashoka Global Academy for Social Entrepreneurship. Accessed October 20. http://ashokau.org/wp-content/uploads/2011/04/AshokaU_Handbook_Preview.pdf.

Chen, Shelley. 2012. "Required Annual Minimum Distribution Planning for Private Foundations." Accessed October 23. http://www.frankrimerman.com/online_library/ tax/required-annual-minimum-distribution-planning-for-private-foundations.asp.

Dees, J. Gregory. 2001. “The Meaning of 'Social Entrepreneurship.'” Center for Advancement of Social Entrepreneurship (CASE) - The Fuqua School of Business at Duke University.

The F. B. Heron Foundation. 2014. "Frequently Asked Questions.” The F. B. Heron Foundation. Accessed October 24. http://fbheron.org/about-us/faq/.

GIIRS Ratings and Analytics for Impact Investing. 2014. "About GIIRS.” Accessed October 21. http://www.giirs.org/about-giirs/about.

Global Impact Investing Network (GIIN). 2014a. "Impact Investing." Global Impact Investing Network. Accessed October 24. http://www.thegiin.org/cgi-bin/iowa/ investing/index.html.

Global Impact Investing Network (GIIN). 2014b. "Measuring Impact.” Social Impact Investment Taskforce. http://www.thegiin.org/cgi-bin/iowa/resources/research/625.html.

Goldman Sachs. 2014. "Trends in Our Business: Social Impact Bonds." Goldman Sachs. Accessed October 24. http://www.goldmansachs.com/our-thinking/trends-inour-business/social-impact-bonds.html?cid=PS_02_47_07_00_00_00_01.

Levitt, David. 2011. “Unscrambling 'MRIs' and 'PRIs.” Philanthropy Journal. Accessed October 23. http://www.philanthropyjournal.org/resources/ managementleadership/unscrambling-\%E2\%80\%98mris\%E2\%80\%99-and$\%$ E2\%80\%98pris\%E2\%80\%99. 
Murdock, Alex, Rebecca Tekula, and Carmen Parra. 2014. "Responding to Challenge: Comparing Nonprofit Programmes and Pedagogy at Universities in the United Kingdom, Spain, and the United States." NISPAcee Journal of Public Administration and Policy 6 (2): 69-95.

Pache, Anne-Claire, and Imran Chowdhury. 2012. "Social Entrepreneurs as Institutionally Embedded Entrepreneurs: Towards a New Model of Social Entrepreneurship Education." Academy of Management Learning and Education 11 (3): 494-510.

Phills Jr., James A., Kriss Deiglmeier, and Dale T. Miller. 2008. "Rediscovering Social Innovation." Stanford Social Innovation Review 5 (4): 34-43.

Rahman, Noushi, and Rebecca Tekula. 2014. "A Replicable Evaluation Method of Social Entrepreneurship Centers and Programs." Emerging Research Directions in Social Entrepreneurship, edited by Larry Pate and Charles Wankel, 111-123. Dordrecht: Springer.

Rockefeller Foundation. 2014. "Remarks by Dr. Judith Rodin at SOCAP 2014." Accessed October 24. http://www.rockefellerfoundation.org/speechespresentations/remarks-by-dr-judith-rodin-socap-2014.

Roeger, Katie L., Amy Blackwood, and Sarah L. Pettijohn. 2012. The Nonprofit Almanac 2012. Washington, D.C.: Urban Institute.

Salamon, Lester M., S. Wojciech Sokolowsi, and Stephanie L. Geller. 2012. "Holding the Fort: Nonprofit Employment during a Decade of Turmoil." Nonprofit Economic Data Bulletin, 39.

Seelos, Christian, Johanna Mair, Julie Battilana, and M. Tina Dacin. 2011. “The Embeddedness of Social Entrepreneurship: Understanding Variation across Local Communities." In Communities and Organizations, edited by Marquis, Christopher, Michael Lounsbury, and Royston Greenwood, Volume 33: 333-363. Bingley: Emerald Group Publishing.

Tekula, Rebecca, and Archana Shah. Forthcoming. "Impact Investing: Funding Social Innovation and Related Actors." Routledge Handbook of Social and Sustainable Finance, edited by Othmar M. Lehner, Oxford: Routledge.

Tekula, Rebecca, Joseph Morreale, and Jordan Jhamb. 2014. "Social Entrepreneurship: The Case of the United States." Social Entrepreneurship: An Alternative to the Crisis, edited by Parra, C., and C. Ruiz, Barcelona: J.M. Bosch.

Wing, Kennard T., Katie L. Roeger, and Thomas H. Pollak. 2010. "The Nonprofit Sector in Brief: Public Charities, Giving, and Volunteering." The Urban Institute. 


\section{Author Information}

Dr. Rebecca Tekula is the Executive Director of the Helene and Grant Wilson Center for Social Entrepreneurship at Pace University, where she is also an assistant professor of public administration in Dyson College of Arts and Sciences. Her research and teaching interests include social enterprise, nonprofit economics, and governance and performance in the social sector.

Archana Shah is the associate director at the Helene and Grant Wilson Center for Social Entrepreneurship at Pace University. Shah has a bachelor's degree in finance and French from the University of Pennsylvania, and a master's degree in economic development from New York University.

Jordan Jhamb is a research assistant at the Helene and Grant Wilson Center for Social Entrepreneurship at Pace University. An honors college economics student in Dyson College of Arts and Sciences, he has co-authored several reports and articles on nonprofit economics and participated in the university's federal reserve challenge team, which twice won the regional championships at the Federal Reserve Bank of New York, and third place at the Board of Governors in Washington, D.C.

Rebecca Tekula

Executive Director, Helene and Grant Wilson Center for Social Entrepreneurship Assistant Professor, Dyson College of Arts and Sciences

Pace University 163 William Street, 21st Floor

New York, NY 10038

E-mail: rtekula@pace.edu

Telephone: 212-346-1925

Archana Shah

Associate Director

Helene and Grant Wilson Center for Social Entrepreneurship

Pace University 163 William Street, 21 st Floor

New York, NY 10038

E-mail: ashah2@pace.edu

Telephone: 212-346-1326

Jordan Jhamb

Research Assistant

Helene and Grant Wilson Center for Social Entrepreneurship

Pace University

163 William Street, 21st Floor

New York, NY 10038

E-mail: jordan.jhamb@gmail.com

Telephone: 212-346-1028 
